\title{
Inserção internacional e mudança estrutural da balança comercial catarinense nos anos $2000 *$
}

\author{
Adriano de Amarante** \\ William José Borges*** \\ Fernando Pozzobon**** \\ Daniel Augusto de Souza*****
}

\begin{abstract}
Resumo
Neste artigo, propõe-se analisar a evolução da balança comercial de Santa Catarina e a mudança na sua estrutura nos anos 2000. Neste estudo exploratório, pautou-se pela análise descritiva de dados e informações de pesquisas quantitativa e qualitativa. A análise descritiva teve-se como suporte adicional a abordagem Neo-Institucionalista, para direcionar e contextualizar o ambiente em que a economia catarinense se insere no comércio internacional, com influência de acordos internacionais e de blocos econômicos. Os resultados são a mudança nas origens e destinos das mercadorias comercializadas, com destaque ao ganho de participação nos valores das importações e exportações por parte da economia Chinesa, e a redução na diversificação da pauta de exportação ao final da segunda década dos anos 2000.
\end{abstract}

Palavras-chave: Balança comercial de Santa Catarina; Importações; Exportações; Teoria institucional.

\section{International insertion and structural change of the Balance of Trade in Santa Catarina in the 2000s}

\begin{abstract}
In this article, it is proposed to analyze the evolution of the trade balance of Santa Catarina and the change in its structure in the 2000s. In this exploratory study, it was guided by the descriptive analysis of data and information of the quantitative and qualitative research. The descriptive analysis, the Neo-Institutionalist approach was used as additional support, to guide and contextualize the environment in which the Santa Catarina economy is inserted in international trade, with influence of international agreements and economic blocs. The main results are the change in the origins and destinations of goods traded, with emphasis on the Chinese economy's gain in participation in the values of imports and exports, and the reduction in the diversification of the export agenda at the end of the second period. decade of the 2000s.
\end{abstract}

Keywords: Trade balance of Santa Catarina; Imports; Exports; Institutional theory.

Código JEL: F10; F14; F41.

\footnotetext{
* Agradecemos o apoio da FAPESC pelo fomento aos equipamentos, softwares e estruturas usados no GEA e ao apoio da UDESC e IFSC pela estrutura física e de equipamentos em geral.

** Professor do Departamento de Ciências Econômicas da Universidade do Estado de Santa Catarina (UDESC). E-mail: adriano.amarante@udesc.br

*** Professor do Instituto Federal de Educação, Ciência e Tecnologia de Santa Catarina (IFSC). E-mail: william.borges@ifsc.edu.br

**** Professor do Departamento de Ciências Econômicas da Universidade do Estado de Santa Catarina (UDESC). E-mail: fernando.pozzobon@udesc.br

*****Professor do Departamento de Ciências Econômicas da Universidade do Estado de Santa Catarina (UDESC).E-mail: daniel.souza@udesc.br
} 


\section{Introdução}

No fluxo complexo internacional de bens, serviços e capitais, os governos, empresas e consumidores de blocos e economias nacionais interagem mediante políticas, regras e barreiras específicas que direcionam e limitam o fluxo. No âmbito da economia brasileira, os movimentos de mercadorias, serviços e fatores se originam e se destinam principalmente às economias da China, EUA, MERCOSUL, com destaque para Argentina, e Europa. Certamente, o comércio e os movimentos de capitais da economia brasileira se desenham ao longo da história, principalmente, mediante as estruturas econômicas e as políticas de economia internacional adotadas.

Quando se restringe a análise para uma economia local aberta, mas também inserida na cadeia produtiva nacional, necessita-se delimitar e caracterizar o estado ou a localidade em estudo e neste caso a economia catarinense está arraigada no contexto da economia brasileira e do Cone-Sul.

Neste trabalho pretende-se abordar a temática do movimento de internacionalização da economia catarinense mediante análise exploratória da evolução da balança comercial do Estado e sua pauta de comércio com o resto do mundo. Uma questão que pode ser respondida é: ocorreram significativa mudança na estrutura da pauta de importação e exportação e nas suas origens e destinos a partir dos anos 2000 ?

O objetivo deste estudo é analisar a evolução da estrutura da balança comercial catarinense nos anos 2000, em relação a origem e o destino das importações e exportações e dos itens de pauta mais importantes de cada conta da balança comercial. Para alcançar este objetivo, utiliza-se a abordagem Neo-Institucionalista como alicerce para análise descritiva da evolução temporal e espacial da estrutura da balança comercial catarinense a partir dos anos 2000 e a relação entre importações e exportações, seus destinos e origens e itens de pauta mais importantes de cada conta da balança.

A descrição dos dados leva em consideração a ótica e perspectiva da teoria institucional. Dessa forma, a exploração dos dados considera que existe uma trajetória na economia, cabendo ao pesquisador identificar as evidências do processo a fim de sistematizar. Os principais exemplos dessa ótica se voltam para frentes tecnológicas, concentrações de compras, vendas, estímulos, contextos, entre outros.

Num contexto geral esse artigo se vale de métodos mistos, os quais combinam elementos de análise quantitativa e qualitativa (GIL, 2017). Mais especificamente, a natureza 
desse artigo é exploratória com delineamento de estudo de caso, a qual segundo Gil (2017, p. 26) “... são desenvolvidas com o objetivo de proporcionar visão geral, de tipo aproximativo, acerca de determinado fato".

Para tanto, realiza-se uma pesquisa quantitativa na obtenção de dados secundários oriundos dos saldos da balança comercial em dólares Free on Board (US\$ FOB) por setor da economia catarinense entre os anos 2000 a 2020. A face qualitativa da pesquisa desse artigo consiste no levantamento sobre a interações entre as instituições, com levantamento das políticas econômicas e comerciais internacionais e intranacionais e de mecanismos de inovação. As informações, anteriormente, citadas são coletadas por meio de pesquisa documental dos relatórios e banco de dados em sites governamentais federais e estaduais.

O tratamento e apresentação dos dados quantitativos se vale da aplicação de estatística descritiva, tabelas, gráficos e georreferenciamento das exportações e importações catarinenses. Para facilitar a análise das informações qualitativas, utiliza-se a elaboração de quadros e ilustrações que sintetizam os acordos internacionais, normas e leis definidoras da evolução do contexto institucional e possíveis implicações sobre a trajetória do comércio exterior catarinense.

Este artigo está estruturado em 4 seções. Nessa $1^{\text {a }}$. seção, faz a introdução; na $2^{a}$. seção, apresenta-se uma contextualização da estrutura da economia catarinense seguida de uma revisão da abordagem Neo-Institucionalista; na $3^{\text {a }}$. seção, apresentam-se os dados quantitativos da balança comercial catarinense e realiza-se análise exploratória-descritiva sobre a mudança na estrutura das contas de exportação e importação e das origens e destinos dos principais itens de pauta; e por fim, na $4^{\mathrm{a}}$. seção traçam-se as considerações finais.

\section{O movimento institucional e o território de Santa Catarina}

A discussão teórica, alinhada às características de Santa Catarina permitem ao leitor uma ideia de movimento institucional e consolidação de um ecossistema próprio no Brasil. Inicialmente, apresentam-se os debates teóricos a respeito da teoria Neo-Institucional e, em seguida, a caracterização dos setores do referido estado.

\subsection{Abordagem Neo-Institucionalista}

O movimento institucional, que também pode ser observado nos resultados econômicos, é analisado na academia por meio das relações entre as entidades. Essas interações, sejam elas 
formais ou informais, sinalizam um comportamento da vida humana e podem contribuir com a compreensão das trajetórias seguidas por uma sociedade

A abordagem institucional avançou na análise da economia, enfatizando novas lentes para se observar os significados das interações sociais. Autores como Geoffrey Hodgson, Warren Samuels e William Dugger procuram, cada um com seu próprio método científico, identificar nas instituições os hábitos da sociedade, suas origens, funções, significados, entre outros interesses.

Com o tempo, as abordagens institucionais (HODGSON, 1998; NORTH, 1990; NELSON, 1995) sinalizaram que as estruturas da vida compõem substancialmente o material da vida social. Nesse sentido, o tratamento das informações geradas pelas instituições na vida comum, envolve o reconhecimento e análise de uma grande variedade de interações e atividades humanas, que vez ou outra estão estruturadas em termos de regras explícitas e implícitas. A balança comercial, por exemplo, resulta de uma agregação da balança de bens e serviços transacionados na economia. Dessa forma, o movimento institucional pode ser observado pelo fluxo de dinheiro, pesos, medidas, contratos, consumo, entre outras instituições.

Naturalmente, os resultados da interação humana levam um tempo para serem observados e explicados na economia, pois existe uma disparidade do status ontológico e explicativo (HODGSON, 2001) das instituições. Além das influências nas trajetórias, a amplitude de vida das instituições é diferente, muitas vezes, observadas, inclusive, de forma longitudinal ao se atualizarem ao longo do tempo.

Portanto, a tentativa de se estabelecer explicações dos processos causais envolvidos é complexa, perfazendo as influências de cima para baixo que ocorrem na interação indivíduo/instituição. Veblen (1899, p. 190) sinalizou que o olhar deveria estar no processo, pois "a situação de hoje molda as instituições de amanhã através de um processo seletivo e coercitivo, através da ação sobre a visão habitual do homem em relação às coisas".

Neste contexto, desde a obra de Veblen, os últimos 122 anos deixaram evidências de que existe uma correlação entre o desenvolvimento das instituições e o desenvolvimento econômico. Para Pessali e Dalto (2010) a interação está pautada em um processo cumulativo e circular, onde as interações ocorrem e, com elas, forma-se uma verdadeira espiral de mudanças.

Essas mudanças ocorrem com interesses amplos, ponderando bem-estar e liberdade dos indivíduos, mas também, sofrendo influências do funcionamento das instituições existentes. North (2005) reforçou a discussão sobre a necessidade de se compreender o processo como um 
todo, as mudanças diárias (portanto complexas de serem sistematizadas) explicam os fenômenos de mudanças, como o de crescimento de um território por exemplo.

Com o passar dos tempos, os indivíduos disseminam os hábitos e reafirmam os seus valores perante a sociedade. Ainda que os indivíduos queiram preservar seus hábitos (VEBLEN, 1973), há uma constante mudança devido ao caráter cumulativo das relações. Ao interpretar Veblen, Dewey (1950) e Monastério (1998) defendem que os hábitos se mostram em atividades e reflexões humanas. Dessa forma, os dados gerados nas interações institucionais representam um agrupamento complexo de interesses de um território e, como consequência, influenciam no seu desenvolvimento.

Com isso, as instituições, no ponto de vista de Pessali e Dalto (2010), não apenas têm o poder de determinar limites, mas também conseguem promover mudanças na medida em que moldam o conhecimento. A partir disso, os movimentos institucionais (compra, venda, absorção tecnológica, atualização de leis, etc.) podem explicar, mediante seu caráter cumulativo, a capacidade de construir novos cenários para a sociedade.

Ao institucionalizar os hábitos de uma sociedade, ocorre a formação de comportamentos convencionais (CONCEIÇÃO, 2012), influenciados pelos interesses e princípios da sociedade por projetos para o seu próprio território. Assim, os indivíduos influenciam, mas também são influenciados por suas instituições ao se estruturar, mudar, restringir, perceber, transacionar, etc. Enfim, as novas preferências e intenções que emergem acabam fortalecendo e tornando as instituições perenes.

Os números da economia, por exemplo, simbolizam essas preferências, gostos e desejos devido à capacidade de estruturação, mudança e restrição que as instituições sociais exercem sobre a comunidade. Para Hodgson (2001) o próprio mercado é uma instituição perene, envolvendo normas sociais, costumes, relações de troca institucionalizadas e redes de informações. Assim, todo o mercado e suas relações de trocas são complexas e interdependentes.

Essa interdependência torna evidente a forma como as instituições operam. Hodgson (2006) defende que é preciso considerar não só os incentivos e desincentivos envolvidos, mas também como os agentes a interpretam e a valorizam. Consequentemente, as interações coadunam com todos os regramentos no campo institucional. No âmbito das regras formais, por exemplo, para que as leis se tornem regras no sentido discutido acima, elas têm de tornarse habituais. 
E, então, a sociedade se depara com novas formas e produtos para se fazer as atividades no dia a dia, tornando o "novo" habitual como um status normativo. Economistas institucionalistas argumentam que as instituições funcionam porque as regras compartilhadas são incorporadas, em grande parte, nos hábitos e comportamentos. Dessa forma, os agentes de mercado iniciam as compras de novos produtos e serviços, baseados nas novas preferências.

Os números da economia sinalizam essa mudança, evidenciando, por exemplo, frentes tecnológicas, concentrações de compras, vendas, entre outros números. Entende-se que na medida em que um hábito se torna uma disposição para se engajar em comportamentos ou pensamentos anteriormente adotados ou adquiridos, desencadeia-se um novo estímulo dentro de um contexto apropriado.

Presumivelmente, o contexto passa a ter importância nesse processo. Quando um território auxilia na legitimação das instituições, contribuindo para gerar confiança em relação a ela, contando com cruciais poderes simbólico e mesmo legislativo. É por isso que as escolhas do indivíduo não são de sua única propriedade (HODGSON, 2001) e conhecimento. A propriedade intelectual não é mera possessão, pois envolve direitos socialmente reconhecidos e vigentes. Não se trata de uma simples relação entre indivíduo e objeto, o contexto contribui com um aparato de reconhecimento, julgamento e imposição, suficientemente poderoso, habitual e legal.

Isso contribui com o entendimento dos diferentes processos de desenvolvimento que podem acontecer em um território. Como os hábitos não são uma única propriedade do indivíduo, a forma com que os grupos (pessoas, empresas, estado, etc.) tratam as instituições podem gerar diferenciação ao longo da trajetória. Mecanismos de inovação feitos pelo estado, por exemplo, podem induzir atividades complementares de inovação ao passo que as instituições se articulam e criam mecanismos de disseminação dos seus resultados nos âmbitos culturais, sociais e econômicos.

Da mesma forma, algumas (mas não todas) as normas jurídicas têm um elemento de autopoliciamento forte (CONCEIÇÃO, 2000). Por exemplo, há incentivos óbvios (além de evitar sanções legais) para respeitar a Lei $\mathrm{n}^{\circ}$ 13.243/2016 com todos os estímulos ao desenvolvimento científico, à pesquisa, à capacitação científica e tecnológica e à inovação. Embora possam ocorrer infrações devido às interpretações particulares, existe uma indução para se desenvolver o ecossistema de inovação.

Geralmente, a ideia de que há uma linha divisória entre as instituições que são inteiramente "formais" (Leis) de um lado e inteiramente instituições "informais" (hábito 
pessoal) sobre o outro é falso, porque as instituições "formais" (em qualquer dos sentidos acima) sempre dependem de regras e normas para operar (HODGSON, 2006). Algumas declarações simplesmente codificam os costumes existentes. Outros podem, eventualmente, tornarem-se normas eficazes, mas só através de poderes adicionais, como persuasão, legitimação ou de execução. Para alocar a discussão no plano formal, as instituições "formais" que não têm apoios fortes "informais" são apenas declarações legislativas, não constituindo uma real instituição. Isso não significa que as normas jurídicas não são importantes, mas que elas se tornam importantes, tornando-se incorporadas nos costumes e hábitos.

Finalmente, Hodgson (2000) reconhece que a atividade humana só pode ser compreendida como emergindo em um contexto de instituições pré-existentes. Isso quer dizer que se opera a partir de restrições institucionais e causação de cima para baixo sobre os indivíduos. Como efeito de segunda ordem, as interações entre os indivíduos dão lugar a novas formas institucionais que servirão de base para novas organizações. Sugere-se, aqui, que a emergência e a estabilidade de algumas instituições podem ser reforçadas por processos em que restrições e canais institucionais levam a formação de hábitos de pensamento e comportamento concordantes.

Esses argumentos indicam uma abordagem mais ampla da evolução de instituições, diminuindo a importância de comparações estáticas em favor de análises baseadas em processos e algoritmos. Na consideração de evolução mais aberta com relação aos fins, tanto de instituições quanto de preferências individuais, tais argumentos remetem ao velho institucionalismo, embora uma especificação detalhada de mecanismos de causa e efeito de cima para baixo estivesse frequentemente ausente naquela literatura. São também evidenciadas ligações com resultados que enfatizam o papel de restrições no comportamento sistemático de uma economia.

\subsection{Análise da estrutura da economia catarinense a luz da teoria Neo- Institucionalista}

O território de Santa Catarina é de apenas 95,7 mil km², o menor estado do Sul do Brasil. O estado é dividido em oito principais regiões geográficas: Litoral, Nordeste, Planalto Norte, Vale do Itajaí, Planalto Serrano, Sul, Meio-Oeste e Oeste. Localizado no Brasil próximo aos grandes centros econômicos da América Latina e posição estratégica no Mercosul.

Santa Catarina faz fronteira ao norte com o território paranaense, ao sul com o estado do Rio Grande do Sul, ao oeste com a Argentina e fronteira marítima com o Oceano Atlântico. 
Tem população estimada de 7,165 milhões de habitantes distribuídos em 295 municípios que juntos possuem uma economia diversificada que representou 4,3\%, em 2018, do Produto Interno Bruto (PIB) brasileiro (IBGE, 2021), o sexto maior PIB do país. O movimento em prol da tecnologia e qualidade dos produtos os qualificam internacionalmente com parcerias comerciais relevantes com países como China, EUA, Japão, Argentina e Chile.

Figura 1 - Concentração dos setores produtivos pelo valor adicionado (VA) de Santa Catarina em 2019.

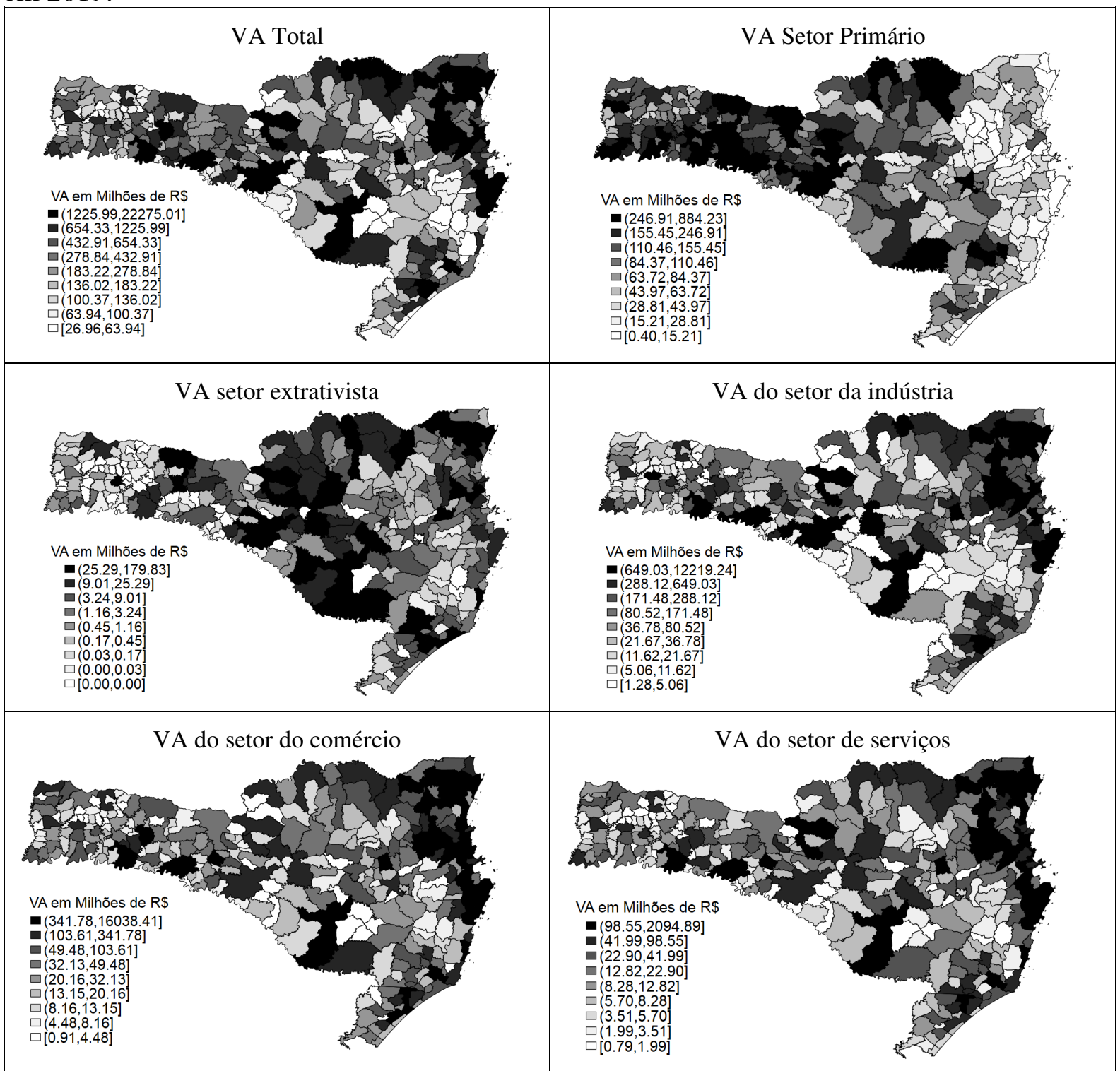

Fonte: Elaboração dos autores com base em SEF-SC (2021).

A composição do PIB estadual é diversificada, cada região possui suas particularidades e perfil produtivo. A Figura 1 permite a visualização da distribuição e concentração das atividades pelo território catarinense. Nota-se que as concentrações fazem parte do arranjo 
institucional de cada território, uma vez que o adensamento produtivo leva em consideração conhecimentos, políticas, empresas, hábitos, entre outras instituições.

É possível perceber, por exemplo, a importância da região oeste para produção no setor agropecuário e também a menor participação da região metropolitana e do litoral norte nesse setor, enquanto a região da serra e planalto norte tem um importante destaque no setor extrativista com alguns municípios de destaque também na região oeste.A indústria é bastante forte no Litoral Norte e Vale do Itajaí, mas existem também importantes cidades na Serra (como Lages), no Oeste (como Chapecó) e Meio-Oeste (como Concórdia). O setor industrial é o que apresenta um maior valor agregado médio nos municípios catarinenses e tem um grande papel na cadeia produtiva do estado.

Na parte de comércio e serviços, as distribuições espaciais são semelhantes e as maiores concentrações em termos de valor agregado estão no litoral e norte com bastante destaque para a região da capital e metropolitana, cidades na serra e oeste também se destacam nesses setores, embora com menor participação.

Tabela 1 - Top 20 principais atividades econômicas catarinenses em 2019

\begin{tabular}{l|c} 
Atividades Econômicas & $\begin{array}{c}\text { Valor } \\
\text { Adicionado }\end{array}$ \\
\hline Produção Primária & $14,943 \%$ \\
\hline Geração, transmissão e distribuição de energia elétrica & $5,925 \%$ \\
\hline Comércio atacadista especializado em outros produtos & $4,713 \%$ \\
\hline Comércio atacadista de produtos de consumo não alimentar & $4,479 \%$ \\
\hline Comércio varejista não especializado & $4,378 \%$ \\
\hline Confecção de artigos do vestuário e acessórios & $3,486 \%$ \\
\hline Transporte rodoviário de carga & $3,325 \%$ \\
\hline Comércio atacadista especializado em produtos alimentícios, bebidas e fumo & $2,901 \%$ \\
\hline Abate e fabricação de produtos de carne & $2,884 \%$ \\
\hline Comércio varejista de produtos novos não especificados anteriormente e de produtos usados & $2,630 \%$ \\
\hline Fabricação de produtos de material plástico & $2,273 \%$ \\
\hline Comércio varejista de equipamentos de informática e comunicação; equipamentos e artigos & $1,643 \%$ \\
\hline de uso doméstico & $1,639 \%$ \\
\hline Telecomunicações por fio & $1,637 \%$ \\
\hline Comércio atacadista não especializado & $1,377 \%$ \\
\hline Comércio varejista de material de construção & $1,326 \%$ \\
\hline Fabricação de eletrodomésticos & $1,281 \%$ \\
\hline Fabricação de outros produtos alimentícios & $1,202 \%$ \\
\hline Comércio de peças e acessórios para veículos automotores & $1,195 \%$ \\
\hline Restaurantes e outros serviços de alimentação e bebidas & $1,104 \%$ \\
\hline Fabricação de produtos de madeira, cortiça e material trançado, exceto móveis & \\
\hline Font Elaboração dos autors com base em SEF-SC (2021) & \\
\hline
\end{tabular}

Fonte: Elaboração dos autores com base em SEF-SC (2021). 
As atividades produtivas são consistentes, e permitiram que o PIB do estado evoluísse ao longo dos anos. Em valores correntes, o PIB catarinense ano de 2000 era de R \$ 42,4 bilhões, no ano de 2010 foi de $\mathrm{R} \$ 130,5$ bilhões e em 2018 foi de $\mathrm{R}$ \$298,2 bilhões. Historicamente o estado apresentou PIB per capita acima da média nacional com sua composição fortemente centrada na indústria, comércio e serviços.

As principais atividades econômicas de Santa Catarina são descritas na Tabela 1 apresentada a seguir e demonstram a relevância de setores tradicionais na economia catarinense. A seleção da referida tabela demonstra a participação no valor adicionado das vinte principais atividades econômicas que, juntas, contabilizaram aproximadamente $64 \%$ de todo o valor adicionado no ano de 2019. O Gráfico 1 contribui com a visualização e entendimento do panorama atual da produção a partir dos setores econômicos.

Gráfico 1: Distribuição da produção, via valor adicionado, a partir dos setores econômicos em SC em 2019.

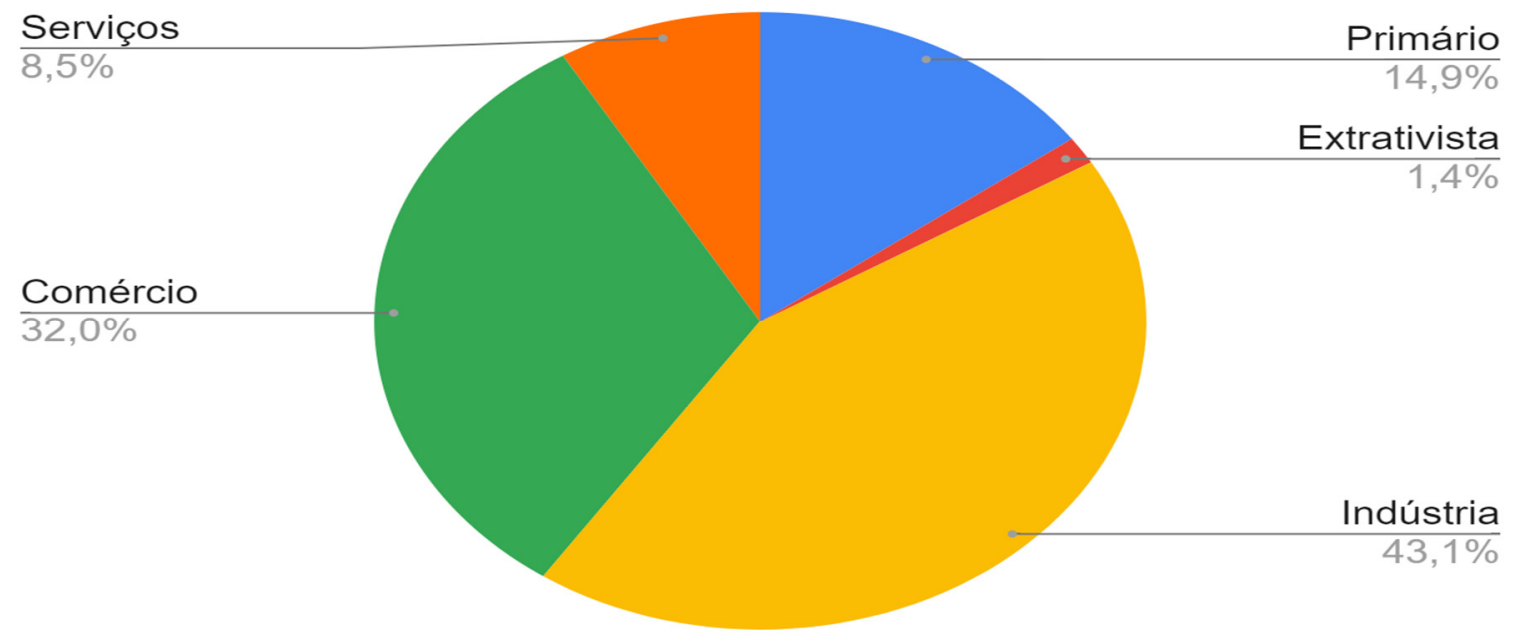

Fonte: Elaboração dos autores com base em SEF-SC (2021).

Por ser um estado dinâmico, Santa Catarina apresenta boas relações comerciais não apenas com outros estados do Brasil, mas também com o resto do mundo. Segundo MDIC (2021), Santa Catarina foi o $3^{\circ}$ maior estado importador do Brasil, e o $9^{\circ}$ maior exportador do país em 2020, e o Gráfico 2 mostra a evolução temporal da balança comercial catarinense.

A balança comercial constitui objeto de análise mais detalhada nas seções a seguir, mas o Gráfico 2 já apresenta a trajetória ao longo dos anos a partir do valor de importações, exportações, taxa de câmbio e saldo da balança comercial e demonstra que houveram alterações importantes ao longo dos últimos 20 anos. A dinâmica evidenciada mostra que o comportamento dos dados de importação, exportação, saldo comercial e taxas de câmbio pode ter sofrido influência de mudanças institucionais nas últimas duas décadas. 
Assim o desenho metodológico, exposto a seguir, permite uma análise exploratória das principais características da balança comercial catarinense. Suas contas e itens possibilitam uma leitura mais detalhada das principais tendências dos anos 2000 e possibilita uma visão macro das concentrações regionais existentes. Cabe o destaque de que a partir de 2010, o saldo dessa balança tem se mostrado negativo para o estado, demonstrando que os valores a preços de embarque foram maiores para as importações em relação às exportações.

Gráfico 2 - Evolução da balança comercial de Santa Catarina e taxa de câmbio.

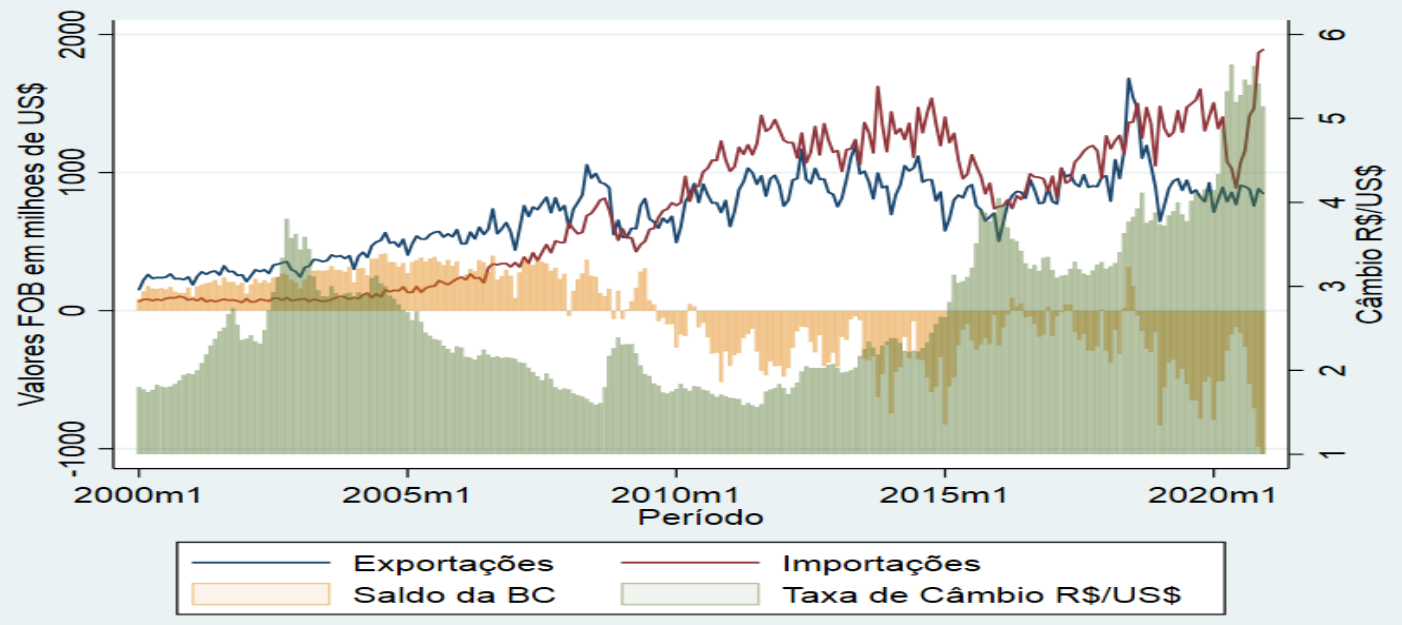

Fonte: Elaboração dos autores com base em MDIC (2021).

\section{Evolução e mudança estrutural da balança comercial de Santa Catarina}

A economia de Santa Catarina apresenta, em seus setores, diferenciações importantes quando comparada aos dados do Brasil como um todo. Características de clima, relevo, geografia, colonização, capital instalado, qualificação de mão de obra, dentre outros fatores trazem vantagens (e também limitações) produtivas que ajudam a explicar essas diferenças e contribuem para entender, em algum grau, as mudanças que vêm ocorrendo no perfil da balança comercial catarinense.

As imagens em mapas apresentadas na Figura 2, favorecem a análise visual das concentrações como um todo. Além disso, o presente texto oferece um olhar longitudinal ao passo que considera os anos 2000, 2010 e 2020. A concentração das exportações muda de maneira mais lenta quando comparada às importações. Há uma relação importante entre as regiões tipicamente industriais que se adensaram e o valor adicionado. Essas regiões são as mesmas que apresentam um maior valor Free On Board de Santa Catarina. 
No contexto da distribuição espacial das exportações, não se observaram alterações significativas entre os anos de 2000 e 2020. É possível notar que as regiões com perfil exportador se mantêm relativamente estáveis (com exceção da região Nordeste que parece ter intensificado os um volume maior dos valores exportados em menos municípios). Quanto à distribuição regional das importações, ocorreu um espraiamento na região Nordeste com alguns municípios ganhando importância em termos de valores de importação.

Figura 2 - Exportações e importações catarinenses FOB em milhões de US\$ entre 2000, 2010 e 2020.

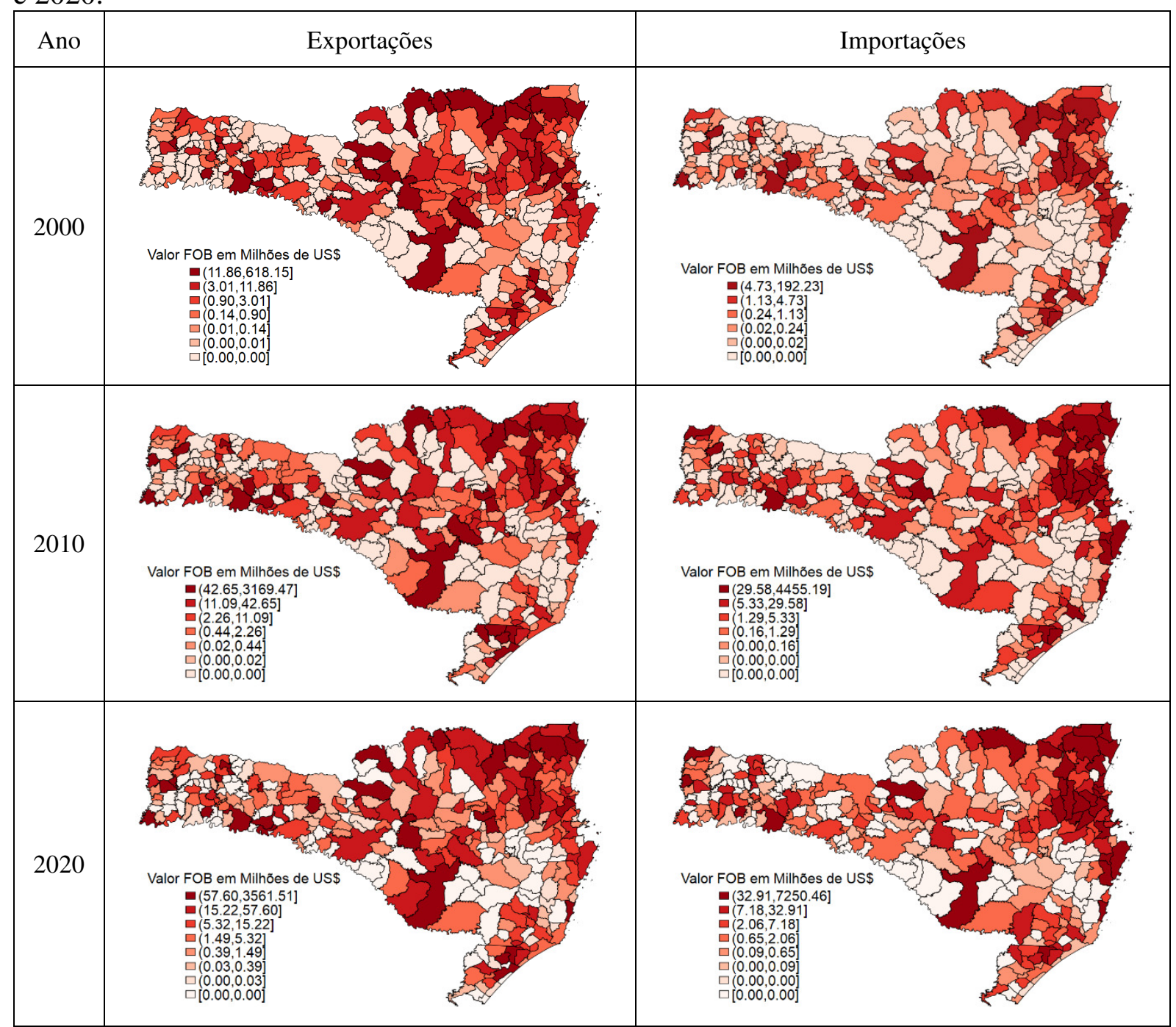

Fonte: Elaboração dos autores com base em MDIC (2021).

Cabe destacar que, de maneira geral, os municípios que concentraram o maior valor de exportações figuraram, também, como os maiores importadores, o que sugere uma possível integração dessas regiões com as cadeias de comércio globais. Naturalmente, os setores importadores e exportadores foram os mesmos em todas as regiões, e se diferenciam ao longo dos anos. Existem mudanças significativas na composição dos principais parceiros comerciais 
e, nesse contexto, torna-se importante entender quais são os principais agentes internacionais desse comércio e investigar as alterações setoriais nessa pauta.

\subsection{Parceiros do comércio exterior de Santa Catarina}

Com o objetivo de analisar a dinâmica regional e estrutural da balança comercial de Santa Catarina e as ligações comerciais com o resto do mundo, torna-se importante identificar e investigar os parceiros comerciais. Neste aspecto, investiga-se os principais acordos e Blocos Comerciais mostrando a evolução da participação do comércio com os parceiros mais importantes.

As Figuras 3 e 4 mostram a evolução temporal e o panorama atual dos principais parceiros comerciais de Santa Catarina. É possível perceber que houve uma alteração bastante grande na participação percentual dos países ao longo do tempo, com destaque para o grande crescimento do mercado chinês na pauta do comércio exterior catarinense, e a menor participação relativa de atores que foram muito importantes no início dos anos 2000 como Estados Unidos.

A construção de acordos bilaterais entre Brasil e China e a formação de acordos multilaterais político-econômicos entre Brasil, Rússia, Índia, China e África do Sul (BRICS), possivelmente contribuíram com mecanismos de incentivos para com o aumento significativo da participação do comércio entre a economia catarinense e a China.

O BRICS, por exemplo, sendo um agrupamento econômico composto pelos países citados, com pretensões de interagir, constituem um movimento institucional importante na economia. Percebe-se que os movimentos e acordos repercutem nos números da balança comercial. Assim, o bloco econômico se constitui como um mecanismo internacional que o Brasil faz parte, e que influencia nos princípios e comportamentos da agenda e acordos internacionais.

A Tabela 2 mostra a participação relativa de cada país do BRICS nas exportações, importações e volume comercial para o Brasil e para Santa Catarina, bem como o saldo da balança comercial em milhões de US\$ para 2000, 2010 e 2020. Pode-se constatar que a estrutura de relação comercial com os parceiros do BRICS tem se tornado bem semelhante, quando se compara o Brasil com Santa Catarina.

A formação do BRICS tem o propósito de ampla cooperação, conforme ilustra Itamarati $\left(2021^{a}\right)$ nas seguintes áreas: ciência e tecnologia, promoção comercial, energia, saúde, educação, inovação e combate a crimes transnacionais. 
Figura 3 - Participação dos principais destinos das exportações catarinenses e cenário atual, 2000 - 2020

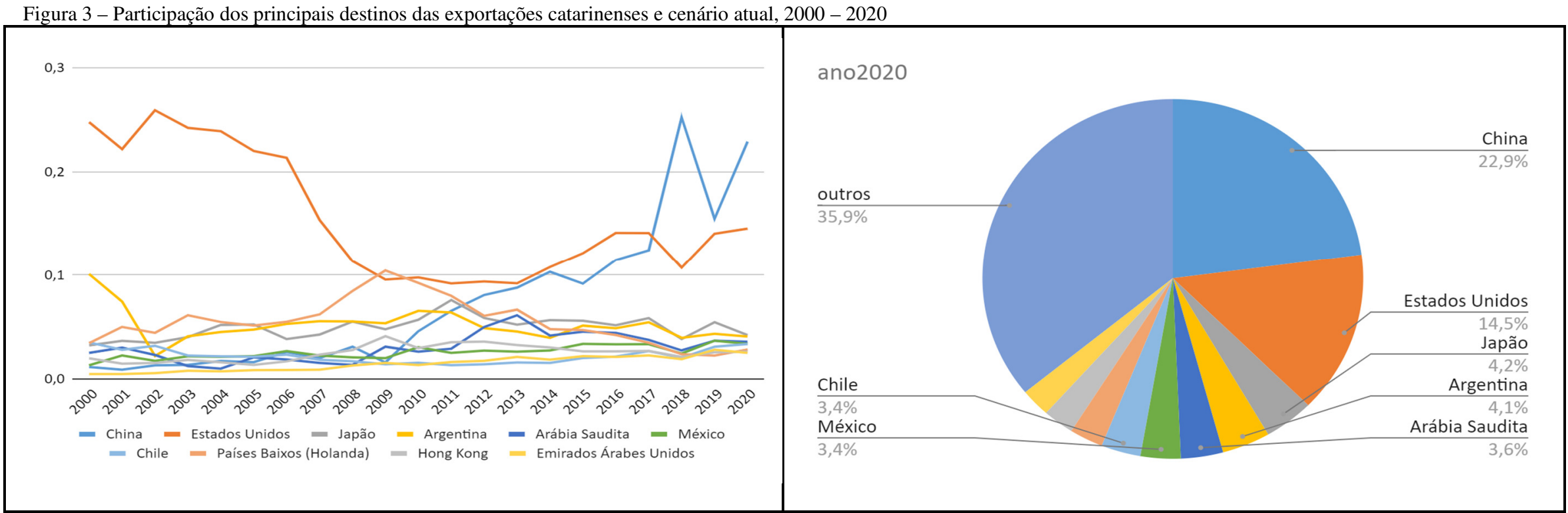

Fonte: Elaboração dos autores com base em MDIC (2021)

Figura 4 - Participação das principais origens da importações catarinenses e cenário atual, 2000 - 2020

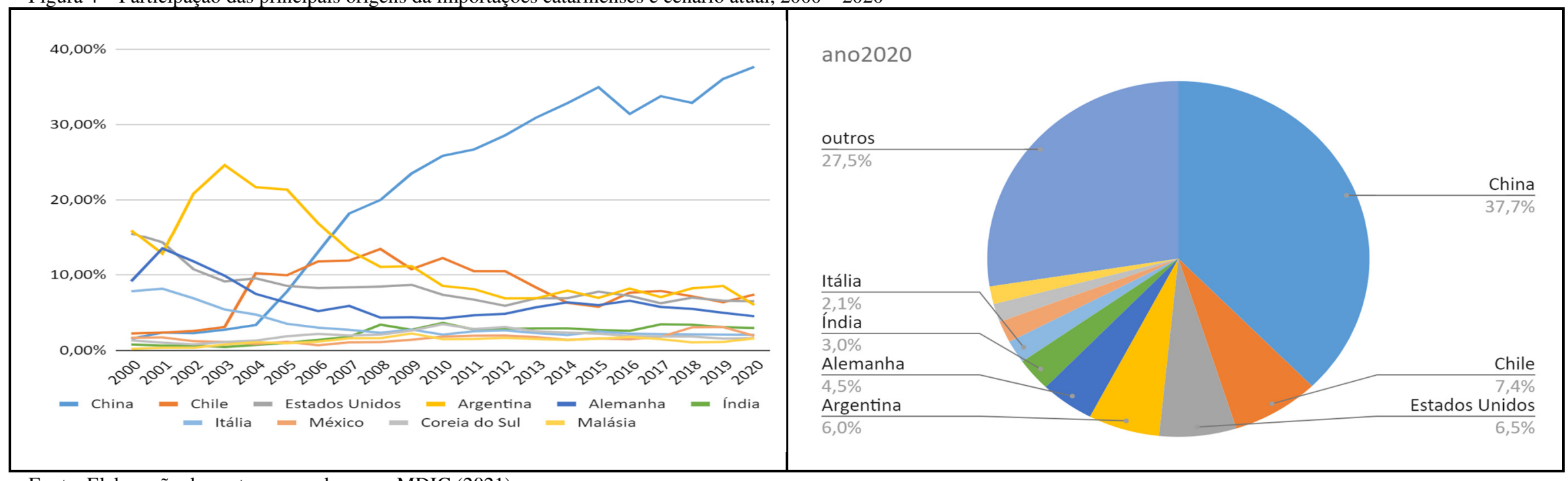

Fonte: Elaboração dos autores com base em MDIC (2021). 
Tabela 2 - Comparativo da balança comercial com os BRICS: Brasil x Santa Catarina, 2000, 2010 e 2020.

\begin{tabular}{|c|c|c|c|c|c|c|c|}
\hline & & \multicolumn{3}{|c|}{ BRASIL } & \multicolumn{3}{|c|}{ SANTA CATARINA } \\
\hline & & 2000 & 2010 & 2020 & 2000 & 2010 & 2020 \\
\hline \multirow{4}{*}{ Exportações } & China & $53,54 \%$ & $77,46 \%$ & $92,62 \%$ & $28,15 \%$ & $37,50 \%$ & $90,29 \%$ \\
\hline & Rússia & $20,87 \%$ & $10,45 \%$ & $2,08 \%$ & $34,31 \%$ & $40,83 \%$ & $2,95 \%$ \\
\hline & África do Sul & $14,87 \%$ & $3,30 \%$ & $1,35 \%$ & $30,08 \%$ & $18,40 \%$ & $5,16 \%$ \\
\hline & Índia & $10,72 \%$ & $8,79 \%$ & $3,94 \%$ & $7,46 \%$ & $3,27 \%$ & $1,59 \%$ \\
\hline \multirow{4}{*}{ Importações } & China & $53,20 \%$ & $78,75 \%$ & $82,21 \%$ & $40,72 \%$ & $81,74 \%$ & $90,24 \%$ \\
\hline & Rússia & $24,95 \%$ & $5,88 \%$ & $6,49 \%$ & $16,19 \%$ & $4,49 \%$ & $1,82 \%$ \\
\hline & África do Sul & $10,00 \%$ & $2,32 \%$ & $1,45 \%$ & $22,04 \%$ & $2,19 \%$ & $0,75 \%$ \\
\hline & Índia & $11,86 \%$ & $13,06 \%$ & $9,85 \%$ & $21,05 \%$ & $11,58 \%$ & $7,19 \%$ \\
\hline \multirow{4}{*}{$\begin{array}{l}\text { Saldo (em } \\
\text { milhões de } \\
\text { US\$) }\end{array}$} & China & $-134,35$ & $5.156,06$ & $33.009,64$ & 16,46 & $-2.585,75$ & $-3.771,40$ \\
\hline & Rússia & $-148,94$ & 2237,34 & $-1223,52$ & 26,43 & $-217,61$ & $-352,36$ \\
\hline & África do Sul & 72,09 & 555,88 & 376,79 & 33,22 & 299,00 & $-47,15$ \\
\hline & Índia & $-54,58$ & $-752,72$ & $-1282,71$ & $-0,07$ & $-43,56$ & $-9,63$ \\
\hline \multirow{4}{*}{$\begin{array}{l}\text { Volume de } \\
\text { comércio }\end{array}$} & China & $53,36 \%$ & $78,04 \%$ & $88,81 \%$ & $31,35 \%$ & $71,30 \%$ & $90,26 \%$ \\
\hline & Rússia & $23,03 \%$ & $8,39 \%$ & $3,70 \%$ & $27,78 \%$ & $13,19 \%$ & $6,64 \%$ \\
\hline & África do Sul & $12,29 \%$ & $2,86 \%$ & $1,39 \%$ & $29,70 \%$ & $13,06 \%$ & $2,13 \%$ \\
\hline & Índia & $11,32 \%$ & $10,71 \%$ & $6,11 \%$ & $11,17 \%$ & $2,45 \%$ & $0,98 \%$ \\
\hline
\end{tabular}

Fonte: Elaboração dos autores com base em MDIC (2021).

No âmbito do BRICS destaca-se a prevalência dos negócios de Santa Catarina com a China, notoriamente desfavorável à economia Catarinense, conforme pode ser vislumbrado nos últimos resultados da balança comercial da Tabela 2 .

Rodrigues (2021) alerta que é fundamental que os estados sul-americanos pactuem acertos institucionais que garantam que as relações comerciais, os investimentos e os acordos multilaterais contemplem que transferências de tecnologias e conhecimento ocorram, e que sejam criados mecanismos de incentivos para o escoamento de produtos manufaturados da região para o mercado chinês.

No Quadro 1 apresenta-se uma síntese dos principais temas e decisões abordados entre as instituições formais pelas cúpulas dos BRICS. 
Quadro 1 - Síntese dos temas e decisões em reuniões do BRICS.

\begin{tabular}{|c|c|}
\hline CÚPULA & PRINCIPAIS TEMAS/DECISÕES ABORDADOS \\
\hline $\begin{array}{l}\text { CÚPULA DE } \\
\text { ECATERIMBURGO } \\
(2009)\end{array}$ & A cúpula inaugurou a cooperação entre os Chefes de Estado e de Governo. \\
\hline $\begin{array}{l}\text { CÚPULA DE } \\
\text { BRASÍLIA I (2010) }\end{array}$ & $\begin{array}{l}\text { Defesa de temas referentes à reforma do Sistema Financeiro Mundial. } \\
\text { Assinatura do acordo de cooperação para facilitação do financiamento de obras e } \\
\text { projetos de energia e infraestrutura. } \\
\text { Os bancos de desenvolvimento firmaram entendimento para estudar maneiras de } \\
\text { ampliar a concessão de crédito entre os BRICs. }\end{array}$ \\
\hline $\begin{array}{l}\text { CÚPULA DE } \\
\text { SANYA* } \\
\text { *(Inclusão da África } \\
\text { do Sul) (2011) }\end{array}$ & $\begin{array}{l}\text { Reafirma a necessidade de reforma da governança global, inclusive do Conselho de } \\
\text { Segurança. } \\
\text { Discussões de temas como: economia e finanças; condenação ao terrorismo; } \\
\text { incentivo ao uso de energias renováveis e ao uso pacífico de energia nuclear; } \\
\text { compromisso com os Objetivos de Desenvolvimento do Milênio e com a } \\
\text { erradicação da fome e da pobreza. }\end{array}$ \\
\hline $\begin{array}{l}\text { CÚPULA DE NOVA } \\
\text { DÉLHI (2012) }\end{array}$ & $\begin{array}{l}\text { Defenderam-se candidaturas de representantes de países em desenvolvimento para } \\
\text { a presidência do Banco Mundial. } \\
\text { Discussões preliminares para a criação do Novo Banco de Desenvolvimento. De } \\
\text { modo a promover o comércio entre os países do BRICS, foi assinado acordo para } \\
\text { facilitação da concessão de crédito em moeda local. }\end{array}$ \\
\hline $\begin{array}{l}\text { CÚPULA DE } \\
\text { DURBAN (2013) }\end{array}$ & $\begin{array}{l}\text { Teve como tema "BRICS e África: Parceria para o Desenvolvimento, Integração e } \\
\text { Industrialização". }\end{array}$ \\
\hline $\begin{array}{l}\text { CÚPULA DE } \\
\text { FORTALEZA (2014) }\end{array}$ & $\begin{array}{l}\text { Foram criados: } \\
\text { 1. Novo Banco de Desenvolvimento (NDB), com o objetivo de mobilizar } \\
\text { recursos para o financiamento de projetos de infraestrutura e } \\
\text { desenvolvimento sustentável em países em desenvolvimento. } \\
\text { 2. Arranjo Contingente de Reservas (ACR), destinado a prover apoio mútuo } \\
\text { aos membros do BRICS em eventuais cenários de crise no balanço de } \\
\text { pagamentos. }\end{array}$ \\
\hline $\begin{array}{l}\text { CÚPULA DE UFÁ } \\
(\mathbf{2 0 1 5 )}\end{array}$ & $\begin{array}{l}\text { Aprovação: } \\
\text { 1. Dos acordos constitutivos do Novo Banco de Desenvolvimento e do } \\
\text { Arranjo Contingente de Reservas. } \\
\text { 2. Da "Estratégia para a Parceria Econômica dos BRICS", roteiro para a } \\
\text { diversificação das trocas comerciais e de investimento entre os países } \\
\text { membros. Assinatura de acordos de cooperação entre os Bancos de } \\
\text { Desenvolvimento dos países do BRICS e o Novo Banco de } \\
\text { Desenvolvimento. }\end{array}$ \\
\hline $\begin{array}{l}\text { CÚPULA DE GOA } \\
(\mathbf{2 0 1 6 )}\end{array}$ & $\begin{array}{l}\text { Discussão sobre a recuperação econômica mundial, abordando temas como: } \\
\text { responsabilidade fiscal e social, desenvolvimento do NDB, atração de } \\
\text { investimentos, combate ao terrorismo e crescimento econômico. }\end{array}$ \\
\hline $\begin{array}{l}\text { CÚPULA DE } \\
\text { XIAMEN (2017) }\end{array}$ & $\begin{array}{l}\text { Assinatura: } \\
\text { 1. Do Plano de Ação para Incentivar a Cooperação em Inovação. } \\
\text { 2. Do Plano de Ação do BRICS sobre Cooperação Econômica e Comercial, a } \\
\text { Estratégia do BRICS para Cooperação Aduaneira e o Memorando de } \\
\text { Entendimento entre o NDB e o Conselho Empresarial do BRICS. }\end{array}$ \\
\hline
\end{tabular}




\begin{tabular}{|c|c|}
\hline CÚPULA & PRINCIPAIS TEMAS/DECISÕES ABORDADOS \\
\hline $\begin{array}{l}\text { CÚPULA DE } \\
\text { JOANESBURGO } \\
\text { (2018) }\end{array}$ & $\begin{array}{l}\text { Estabelecimento do acordo relativo à Sede do Escritório Regional das Américas do } \\
\text { Novo Banco de Desenvolvimento, a ser instalado em São Paulo. } \\
\text { Assinou-se o Memorando de Entendimento sobre a Parceria em Aviação Regional. } \\
\text { Aprovou-se a criação da Rede de Inovação do BRICS, a iBRICS. }\end{array}$ \\
\hline $\begin{array}{l}\text { CÚPULA DE } \\
\text { BRASÍLIA II (2019) }\end{array}$ & $\begin{array}{l}\text { Fortalecimento do sistema comercial multilateral, com a Organização Mundial do } \\
\text { Comércio em seu centro. } \\
\text { Acordaram que é essencial que todos os membros da OMC evitem medidas } \\
\text { unilaterais e protecionistas. } \\
\text { Assinatura: } \\
\text { 1. Da Cooperação entre os países do BRICS no campo da aviação civil. } \\
\text { 2. Do Memorando de Entendimento entre Agências de Comércio e Promoção } \\
\text { de Comércio e Investimento do BRICS } \\
\text { 3. Do Acordo acerca do uso contínuo de políticas fiscais, monetárias e } \\
\text { estruturais para alcançar um crescimento forte, sustentável, equilibrado e } \\
\text { inclusivo. }\end{array}$ \\
\hline $\begin{array}{l}\text { XII CÚPULA DO } \\
\text { BRICS - por } \\
\text { videoconferência } \\
(\mathbf{2 0 2 0})\end{array}$ & $\begin{array}{l}\text { Discussão sobre a resposta da comunidade internacional à crise pandêmica e as } \\
\text { ações dos cinco países em matéria de recuperação econômica, inclusão social e } \\
\text { saúde pública. } \\
\text { Realização de apresentações sobre os trabalhos do Novo Banco de } \\
\text { Desenvolvimento; do Conselho Empresarial do BRICS e do Mecanismo de } \\
\text { Cooperação Interbancária. }\end{array}$ \\
\hline
\end{tabular}

As novas frentes de relacionamentos, simbolizadas pelos temas discutidos nas sucessivas reuniões descritas acima, condicionam novas preferências, gostos e desejos das estruturas institucionais. Dessa forma, os números da balança podem ser analisados levando em consideração o contexto e a indução institucional citadas acima. Obviamente, não se pode citar todos movimentos institucionais importantes a la Hodgson (2006), mas posicionar acordos internacionais em seu tempo contribuem com a análise.

Outro relevante instrumento institucional, o Mercosul teve como marco inicial o Tratado de Assunção assinado em 1991, onde foi estabelecido o modelo para a integração de um mercado comum que permita a livre circulação de bens, serviços e fatores de produção, bem como uma necessária adoção de uma política comercial comum e alinhamento de políticas setoriais entre os países membros (ITAMARATI, 1991b).

Atualmente, são Estados Partes do Mercosul o Brasil, Argentina, Paraguai, Uruguai e Venezuela, esta última está suspensa por estar em desacordo com o com o disposto no segundo parágrafo do artigo $5^{\circ}$ do Protocolo de Ushuaia (MERCOSUL, 2021). 
Desde o seu início, o Mercosul realizou 163 acordos de entendimento de variados temas entre os Estados Partes, Estados Associados ${ }^{1}$ e outros países externos e/ou blocos econômicos. A partir do ano de 2000 foram elaborados 24 entendimentos ligados diretamente ao comércio. O Quadro 2 descreve, sucintamente, o que foi tratado em cada um desses acordos.

Quadro 2 - Síntese dos acordos comerciais intra-bloco e entre Mercosul e outros blocos, $2001-2021$

\begin{tabular}{|c|c|}
\hline Países/Blocos & Descrição \\
\hline África do Sul (2000) & Criação de uma zona de livre comércio entre o Mercosul e a África do Sul \\
\hline Índia (2004) & Acordo de comércio preferencial entre o Mercosul e a república da Índia \\
\hline Marrocos (2004) & Acordo de comércio entre o Mercosul e o Reino de Marrocos \\
\hline $\begin{array}{l}\text { União Aduaneira da África } \\
\text { Austral (2004) }\end{array}$ & $\begin{array}{l}\text { Acordo de comércio preferencial entre o Mercosul e a União Aduaneira da África } \\
\text { Austral (SACU) }\end{array}$ \\
\hline $\begin{array}{l}\text { Conselho de Cooperação } \\
\text { dos Estados Árabes do } \\
\text { Golfo (2005) }\end{array}$ & $\begin{array}{l}\text { Acordo de cooperação econômica entre os Estados do Mercosul e os estados } \\
\text { membros do Conselho de Cooperação dos Estados do Golfo Árabe (GCC) }\end{array}$ \\
\hline Israel (2005) & Acordo inicial de comércio entre o Mercosul e o estado de Israel \\
\hline Venezuela (2005) & Adesão da Venezuela ao Mercosul \\
\hline Paquistão (2006) & Acordo inicial de comércio entre o Mercosul e a República Islâmica do Paquistão \\
\hline Cingapura (2007) & $\begin{array}{l}\text { Memorando de entendimento sobre cooperação sobre comércio e investimentos e } \\
\text { plano de ação entre o Mercosul e Cingapura }\end{array}$ \\
\hline Israel (2007) & Tratado de livre comércio entre o Mercosul e o estado de Israel \\
\hline Jordânia (2008) & Acordo comercial entre o Mercosul e a Jordânia \\
\hline Turquia (2008) & Estabelecimento de uma zona de livre comércio entre o Mercosul e a Turquia \\
\hline $\begin{array}{l}\text { União Aduaneira da África } \\
\text { Austral (2008) }\end{array}$ & $\begin{array}{l}\text { Atualização do acordo de comércio preferencial entre o Mercosul e a União } \\
\text { Aduaneira da África Austral (SACU) }\end{array}$ \\
\hline Coréia do Sul (2009) & $\begin{array}{l}\text { Memorando de entendimento para a criação de um grupo de assessoria para a } \\
\text { promoção do comércio e do investimento entre o Mercosul e a Coréia do Sul }\end{array}$ \\
\hline Egito (2010) & Tratado de livre comércio entre o Mercosul e a República Árabe do Egito \\
\hline Síria (2010) & $\begin{array}{l}\text { Acordo para a criação de uma zona de livre comércio entre o Mercosul e a república } \\
\text { árabe da Síria }\end{array}$ \\
\hline Palestina (2010) & $\begin{array}{l}\text { Acordo sobre comércio e cooperação econômica entre o Mercosul e a organização } \\
\text { para a liberação da Palestina, em nome da autoridade nacional da Palestina }\end{array}$ \\
\hline Palestina (2011) & Tratado de livre comércio entre o Mercosul e o Estado da Palestina \\
\hline Tunísia (2014) & Acordo sobre comércio e cooperação econômica entre o Mercosul e a Tunísia. \\
\hline
\end{tabular}

\footnotetext{
${ }^{1}$ Chile, Colômbia, Equador, Guiana, Peru e Suriname são Estados Associados, estando a Bolívia em processo de adesão atualmente.
} 


\begin{tabular}{|l|l|}
\hline Países/Blocos & Descrição \\
\hline Líbano (2014) & $\begin{array}{l}\text { Memorando de entendimento sobre comércio e cooperação econômica entre o } \\
\text { Mercosul e o Líbano }\end{array}$ \\
\hline $\begin{array}{l}\text { Comissão Econômica } \\
\text { Euroasiática (2018) }\end{array}$ & $\begin{array}{l}\text { Memorando de cooperação sobre comércio e assuntos Econômicos entre o } \\
\text { Mercosul e a Comissão Econômica Eurasiana }\end{array}$ \\
\hline Mercosul (2019) & Alteração ao protocolo de Montevidéu sobre o comércio de serviços do Mercosul \\
\hline Mercosul (2019) & Acordo de facilitação comercial \\
\hline Mercosul (2021) & Acordo de comércio eletrônico do Mercosul \\
\hline
\end{tabular}

Fonte: Mercosul, (2021).

Dos Estados Partes pertencentes ao Mercosul, apenas a Argentina consta como relevante para o desempenho da balança comercial de Santa Catarina. E, em relação aos Estados Associados, apenas o Chile tem comércio expressivo com Santa Catarina.

Fora do Mercosul, pode-se considerar que a Coréia do Sul e Arábia Saudita estão entre os dez maiores parceiros comerciais de Santa Catarina. Analisando os resultados dos acordos descritos neste artigo pode-se inferir, ainda que de forma inicial, que o papel dos acordos institucionais no âmbito do BRICS e Mercosul produziram dois tipos de efeitos.

O primeiro diz respeito à intensificação comercial entre Santa Catarina e China, aparentemente mais em função dos efeitos marginais resultantes dos acordos entre Brasil e os outros membros do BRICS. O segundo efeito é a diversificação dos mercados a serem explorados, mas nesse caso, com menor volume comercial, haja vista que a maioria dos parceiros comerciais não constam entre os dez maiores volumes comercializados.

\subsection{Evolução da estrutura temporal e espacial da pauta de exportações e Importações}

$\mathrm{Na}$ esteira das mudanças institucionais, a Figura 5 apresenta um retrato temporal de 2000 e 2010 e o panorama atual dos principais setores de exportação e importação catarinense. Pode-se verificar uma mudança na estrutura das exportações e importações, ao longo das duas décadas para os dez principais itens da pauta.

Em uma visão geral, a primeira década inicia-se com uma relativa diversificação na pauta das contas da balança comercial, que ao final apresenta uma concentração em 3 itens de exportações e 4 itens de importações em 2010. Em 2020, manteve-se a concentração das 
exportações em um item e uma mais equânime distribuição da participação dos outros nove itens. Enquanto isso, a distribuição das importações ficou relativamente menos concentrada, com redução na participação geral dos 5 principais itens.

No início dos anos 2000 os principais itens de exportações, dentre os citados na Figura 5, foram "Máquinas e Aparelhos Material” com participação de 21,3\%, "Animais Vivos e Produtos do Reino Animal" com 15,7\% e "Produtos das Indústrias Alimentícias" com 11,9\%, "Materiais Têxteis e suas Obras" com 11,1\%, e "Animais Vivos e Produtos do Reino Animal" com $10,3 \%$, perfazendo um total de 70,3\%. No contexto das importações os principais itens em 2000 foram "Máquinas e Aparelhos Material" com participação de 30,8\%, "Materiais Têxteis e suas Obras" com 13,7\%, "Produtos da Indústria Química" com 10,6\%, "Produtos do Reino Vegetal" com 10,3\% e "Plástico e suas Obras" com 9,5\% alcançando um total de 74,9\%.

No final da década, no ano de 2010, exportações ficaram concentradas nos setores de “Animais Vivos e Produtos do Reino Animal” com 36,6\% de participação na pauta, seguido dos setores de "Máquinas e Aparelhos Material" com 20,8\%, e de "Produtos das Indústrias Alimentícias" com 17,9\%, que juntos alcançaram uma participação 75,3\% das exportações deste ano.

A tendência das importações não foi diferente e agora somente 4 setores alcançaram uma participação de 74,9\%, foram: "Metais Comuns e suas Obras" com 26,0\%, "Máquinas e Aparelhos Material" com 21,7\%, "Plástico e suas Obras" com 15,0\%, e "Materiais Têxteis e suas Obras" com 12,2\%.

Nesse ponto da análise, pode-se observar que com o passar do tempo o número de setores aumentou e houve uma diminuição da pauta exportadora e importadora. Entende-se que o movimento institucional (NELSON, 1995), notadamente simbolizado pelos acordos internacionais, abrem caminho para as novas empresas transacionarem. Na medida em que há um relacionamento, abre-se um precedente para que outros atores façam uso dos acordos, aumentando, gradativamente, o número de itens importados e exportados ao longo dos 20 anos analisados.

No final da segunda década, em 2020, observou-se uma relativa diversificação das pautas de exportações e importações. No âmbito das exportações um conjunto de 4 itens, um item a mais se comparado ao ano de 2010 , foi suficiente para alcançar a participação de $74,7 \%$, com destaque para o setor de "Animais Vivos e Produtos do Reino Animal" com 38,0\%, e que foi seguido pelas participações dos setores de "Máquinas e Aparelhos Material" com 14,0\%, "Produtos do Reino Vegetal” com 12,0\% e "Madeira, Carvão Vegetal e Outros” com 10,7\%. 
Figura 5: Principais setores exportadores e importadores nos anos 2000, 2010 e 2020.

\begin{tabular}{|c|c|c|c|}
\hline $\begin{array}{l}\text { Exportações SC } 2000 \\
\text { outros } \\
12,4 \% \\
\text { Matérias têxteis e suas obra } \\
11,1 \% \\
\text { Pastas de madeira Papel et_all } \\
3,6 \% \\
\text { Mercadorias e produtos diverso } \\
8,6 \% \\
\text { Metais comuns e suas obras } \\
, 1,1 \% \\
\text { Produtos das indútrias alimen }\end{array}$ & $\begin{array}{r}\text { Animais vivos e produtos do reino animal } \\
15,7 \% \\
\text { Máquinas e aparelhos material } \\
21,3 \% \\
\text { Produtos do reino vegetal } \\
2,2 \% \\
\text { Madeira carvão vegetal all } \\
10,3 \%\end{array}$ & 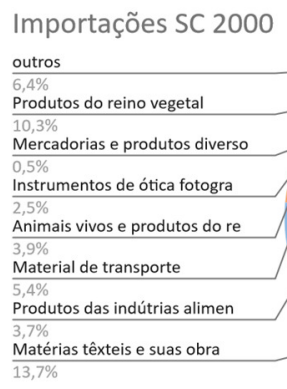 & $\begin{array}{r}\text { Metais comuns e suas obras } \\
\begin{array}{l}2,8 \% \\
\text { Produtos das indústrias quim } \\
10,6 \% \\
\text { Plásticos e suas obras } \\
9,5 \%\end{array}\end{array}$ \\
\hline $\begin{array}{l}\text { Exportações SC } 2010 \\
\text { outros } \\
5,3 \% \\
\text { Mercadorias e produtos diverso } \\
3,1 \% \\
\text { Metais comuns e suas obras } \\
2,6 \% \\
\text { Produtos das indútrias alimen } \\
17,9 \% \\
\frac{\text { Madeira carvão vegetal et_all }}{4,2 \%} \\
\frac{\text { Produtos do reino vegetal }}{4,1 \%}\end{array}$ & $\begin{array}{l}\text { Animais vivos e produtos do reino animal } \\
36,6 \% \\
\text { Máquinas e aparelhos material } \\
20,8 \%\end{array}$ & 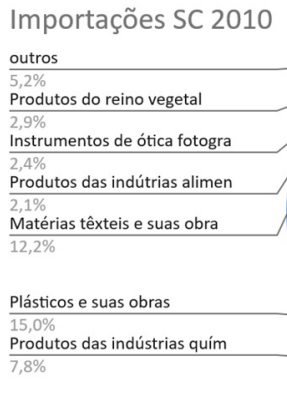 & $\begin{array}{l}\text { Máquinas e aparel hos material } \\
21,7 \%\end{array}$ \\
\hline $\begin{array}{l}\text { Exportações SC } 2020 \\
\text { outros } \\
5,8 \% \\
\text { Produtos das indústrias quím } \\
2,9 \% \\
\text { Metais comuns e suas obras } \\
3,1 \% \\
\text { Produtos das indútrias alimen } \\
6,4 \% \\
\text { Madeira carvão vegetal et_all } \\
10,7 \% \\
\text { Produtos do reino vegetal } \\
12,0 \%\end{array}$ & $\begin{array}{l}\text { Animais vivos e produtos do reino animal } \\
38,0 \% \\
\text { Máquinas e aparelhos material } \\
14,0 \%\end{array}$ & $\begin{array}{l}\text { Importações SC } 2020 \\
\text { outros } \\
5,2 \% \\
\frac{\text { Intrumentos de ótica fotogra }}{2,9 \%} \\
\frac{\text { Animais vivos e produtos do re }}{3,0 \%} \\
\frac{\text { Material de transporte }}{3,7 \%} \\
\frac{\text { Produtos das indútrias alimen }}{4,5 \%} \\
\frac{\text { Matérias têxteis e suas obra }}{10,4 \%} \\
\frac{\text { Plásticos e suas obras }}{13,7 \%}\end{array}$ & $\begin{array}{l}\text { Metais comuns e suas obras } \\
15,2 \% \\
\text { Produtos das indústrias quím } \\
14,2 \%\end{array}$ \\
\hline
\end{tabular}

Fonte: Elaboração dos autores com base em MDIC (2021) 
Ao comparar o ano de 2010 ao ano de 2020, a pauta de importações apresentou uma distribuição mais equilibrada com o reposicionamento da importância do item "Produtos da Indústria Química" com participação relativa maior. Quando se compara o ano de 2000 ao ano de 2020, observou-se uma alternância entre dois itens de pauta com a forte perda de importância de "Produtos do Reino Vegetal" e forte participação em 2020 do item "Metais Comuns e suas Obras".

Os principais itens importados em 2020 foram "Máquinas e Aparelhos Material” com participação de 22,2\%, "Metais Comuns e suas Obras" com 15,2, "Produtos da Indústria Química" com 14,2\%, "Plástico e suas Obras" com 13,7\% e "Materiais Têxteis e suas Obras" com $10,4 \%$ alcançando um total de $75,7 \%$.

Com o propósito de complementar as informações apresentadas na Figura 2, são apresentadas, nas Figuras 6 e 7, a composição espacial dos 4 principais setores de exportação e importação elencados anteriormente. A distribuição espacial da pauta de exportações segue o padrão da localização das atividades produtivas representado pelo Valor Adicionado apresentado na Figura 1.

O setor de "Animais vivos e produtos do reino animal" foi o que apresentou uma tendência a espalhar a produção para exportação por todas as regiões do estado, mas que tem a característica de concentrar a atividade exportadora em poucos municípios de cada região. Para o setor de "Máquinas e aparelhos, material elétrico e suas partes", a região Nordeste manteve sua força exportadora neste item ao longo dos anos 2000. Essa atividade tem se espalhado em regiões do Vale do Itajaí e de maneira localizada em todas as regiões de Santa Catarina.

Ainda dentre as atividades exportadoras, os 'Produtos do Reino Vegetal" se concentraram no Meio-Oeste e Nordeste. De maneira localizada, pode-se encontrar dois municípios na Serra, dois no Litoral, um na região Oeste, e um pequeno agrupamento ao Sul. Para "Madeira, carvão vegetal, e similares" vem ocorrendo uma tendência de concentração da atividade exportadora no Planalto Norte e Planalto Serrano.

Para as importações, a região do Litoral Norte constituiu destaque nos 4 principais setores da pauta. Os municípios com registros de maiores valores de importação foram aqueles que se destacaram nos setores de produção industrial apresentados na Figura 1.

É possível perceber que, muito embora os valores importados tenham aumentado de forma substancial, a configuração espacial se alterou pouco ao longo dos anos, com destaque para "Produtos das indústrias químicas ou indústrias conexas" e "Plásticos e suas obras" que parecem ter se intensificado também para a região metropolitana da capital do estado. 
Figura 6 - Configuração espacial dos principais setores da pauta de exportações catarinenses FOB em milhões de US\$ - 2000, 2010 e 2020



Fonte: Elaboração dos autores com base em MDIC (2021) 
Figura 7 - Configuração espacial dos principais setores da pauta de importações catarinenses FOB em milhões de US\$ - 2000,2010 e 2020

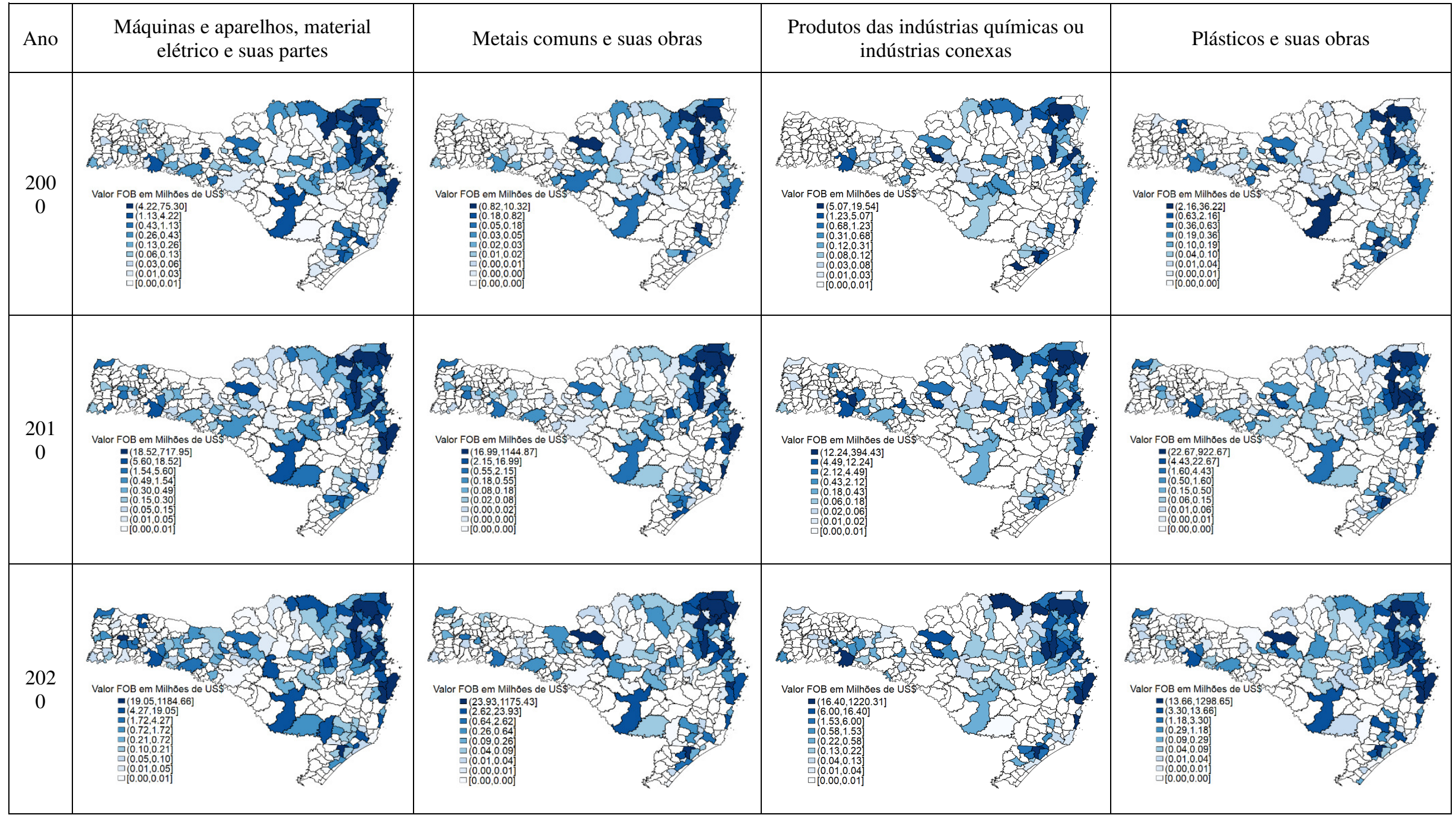

Fonte: Elaboração dos autores com base em MDIC (2021) 
Uma parte desses fenômenos regionais observados no comércio exterior catarinense pode estar relacionado a alterações normativas, já que existe uma recorrência de temas nas leis que induzem o comportamento dos agentes. Entende-se que os números da balança comercial representam um resultado de um comportamento de longa data. Comportamento esse que os agentes do território catarinense vêm criando ambientes especializados e cooperativos. Para isso, fazem uso de reduções fiscais, programas, normas, orientações, incentivos, projetos e demais políticas de apoio em Santa Catarina.

O resgate de Hodgson (2006) nesse momento se faz válido, pois traça linha divisória entre as instituições "formais" e "informais" (hábito pessoal). O movimento presente no estado de Santa Catarina é intenso e representativo. Ao longo dos anos, é possível notar um conjunto de leis que favorecem o desenvolvimento e articulação de mecanismos que representam, induzem e condicionam o comportamento dos catarinenses. Dessa forma, as instituições, em qualquer dos sentidos acima, dependem de regras e normas para operar. A Figura 8 apresenta nuvem de palavras com os principais temas abordados nas legislações e simboliza um conjunto resumido, não completo, de leis e incentivos que ocorreram no estado nos últimos 20 anos.

Figura 8 - Nuvem de palavras com os principais termos das normativas de promoção do comércio exterior catarinense.



Fonte: Elaboração própria com base no levantamento das Leis Estaduais 2000 - 2020.

As nuvens de palavras constituem uma forma visual para identificar quais os termos são mais frequentes em um conjunto textual já que quanto maior o tamanho e destaque maior é a frequência de utilização dessa palavra. Assim, é possível verificar que muitas das normativas têm cunho tributário (por exemplo, aquelas associadas ao ICMS) que visam, em grande parte, flexibilização de impostos ou tratamentos diferenciados. Os objetivos principais estão 
relacionados ao apoio e à promoção de emprego, simplificação das operações e tem grande foco em empresas, para produção de mercadorias e serviços.

\section{Considerações finais}

Do ponto de vista institucional, o papel das instituições, como é o caso do BRICS e Mercosul, tem reflexos sobre o desempenho e mudança da estrutura dos itens das exportações e importações catarinenses. No caso de instituições promovidas por autoridades públicas restritas às políticas de apoio e incentivos econômicos, pode-se inferir a adoção de medida, principalmente, para salvaguardar emprego, renda e modernizar e facilitar as transações.

Dentre as proposições apresentadas neste estudo, pode-se apontar que o fortalecimento da economia chinesa em conjunto com sua estratégia de inserção no comércio internacional, primeiro com sua entrada na OMC, à primeira vista, aceito como um grande mercado consumidor. A partir deste marco, a formação de acordos, com destaque aos BRICS, fortaleceu a economia chinesa um grande fornecedor de uma variedade de bens e serviços, exportando bens com elevada intensidade tecnológica para parceiros como Brasil. Este, possivelmente, foi fator um determinante para uma significativa mudança na estrutura, origens e destinos dos itens da pauta das exportações e importações da economia catarinense. Neste contexto, EUA, Argentina, Alemanha e Itália perderam participação no valor das importações catarinenses, enquanto Chile oscilou positivamente, e China apresentou ganho exponencial de participação na pauta de importação catarinense, durante os anos 2000 até 2020.

Quanto as exportações, a participação das exportações com destino a China teve um crescimento significativo, mas diferente das importações, o ganho de participação iniciou na segunda metade da primeira década dos anos 2000. As exportações com destino aos EUA perderam participação, mas a participação no valor total das exportações permaneceu relevante.

Notadamente, outro resultado importante de registro foi a ocorrência de uma redução na diversificação da pauta de exportação ao final da segunda década dos anos 2000, com o possível enfraquecimento da competitividade da indústria têxtil e ganho de participação das indústrias de alimentos e carnes. Neste sentido, observam-se movimentos de aproximação comercial e econômica que possam gerar marcos relevantes com impactos nas decisões, pautas e desenvolvimento de tecnologias que promovam a melhoria da competitividade. Assim, os dados e informações sobre o intercâmbio de mercadorias plural pode induzir no futuro, novas aproximações nas áreas técnica, científica, cultural, financeira e outros pontos, entre a economia 
catarinense e agentes econômicos de outros países e blocos, com objetivo de diversificação dos mercados externos e redução de dependência com parceiros unilaterais em setores chave.

Nesse contexto, políticas econômicas de locais e estaduais, em conjunto a uma arquitetura de governança de agentes públicos e privados, podem ser mais efetivas e imediatas no aumento da competitividade de empresas catarinenses. A identificação e a análise de setores desenvolvidos em potenciais regiões ou localidades, como apontado pelas ilustrações, podem facilitar e tornar mais promissores investimentos em estruturas de apoio a produção e comércio exterior. No entanto, cabe ressaltar que o sucesso de políticas locais ou estaduais de apoio e incentivos econômicos depende em grande parte de fatores institucionais, como a estabilidade econômica e política de ordem nacional e internacional. Por sua vez, desequilíbrios e contestações de instituições políticas nacionais tendem a enfraquecer o desempenho gerado por medidas, normas e regulamentos de autoridades locais e regionais, favoráveis aos negócios e transações internacionais.

A proposta deste artigo apresenta limitações ao propor hipóteses de possíveis influências das instituições formais e informais sobre o desempenho externo da economia catarinense, mas que, dá origem a uma futura agenda de pesquisa. Uma das limitações do presente artigo é que não se procurou estabelecer relações causais diretas entre as políticas institucionais e o desempenho da balança comercial de Santa Catarina, em um estudo com instrumentos de entrevista aos agentes econômicos, para perceber seus juízos de valor e expectativas quanto ao quadro institucional. Outro ponto é que se limitou a analisar a evolução espacial da distribuição de quatro principais setores de exportação e importação, e talvez, deixando de observar e analisar setores nascentes e mais dinâmicos e tecnológicos. Por fim, uma outra limitação diz respeito a ausência de levantamento de outros acordos bilaterais fora do Mercosul e BRICS.

\section{Referências}

CONCEIÇÃO, O. A. C. Instituições, crescimento e mudança na ótica institucionalista. Tese (Doutoramento em Economia) - Programa de Pós-Graduação em Economia, Universidade Federal do Rio Grande do Sul, Porto Alegre. Porto Alegre, 2000.

Há compatibilidade entre a tecnologia social de Nelson e a causalidade vebleniana de Hodgson? Revista de Economia Política. v. 32, n. 1, janeiro-março, p. 109-127, 2012.

DEWEY, J. Human nature and conduct: an introduction to social psychology. New York: Random House, 1950.

GIL, C. A. Métodos e técnicas de pesquisa social, 7. ed. São Paulo: Atlas, 2019. 
HODGSON, G. M. The approach of institutional economics. Journal of economic literature, v. 36, n. 1, p. 166-192, 1998.

. What is the essence of institutional economics? In: Annual meeting of the association for evolutionary economics. Boston, Massachusetts, 6-9 jan., 2000.

A evolução das instituições: uma agenda para pesquisa teórica futura. Econômica, v. 3, n. 1, p. 97-125, 2001.

. What are Institutions? Journal of Economic Issues. vol.40, n.1, mar., 2006.

ITAMARATY, Ministério das Relações Exteriores. O que é o BRICS. Disponível em: http://brics2019.itamaraty.gov.br/sobre-o-brics/o-que-e-o-brics, Acesso em 30 jul. 2021 a.

ITAMARATY, Ministério das Relações Exteriores. Saiba mais sobre o MERCOSUL. Disponível em: https://www.gov.br/mre/pt-br/assuntos/mercosul/saiba-mais-sobre-omercosul\#dados_basicos. Acesso em 30 jul. 2021b.

LEIS ESTADUAIS DE 2021. Legislação. Disponível em: http://legislacao.sef.sc.gov.br/Consulta/Views/Publico/Frame.aspx? $\mathrm{x}=/$ html/leis/frame_leis.ht m, Acesso em 24 ago. 2021.

MDIC, Ministério da Indústria, Comércio Exterior e Serviços. COMEX STAT. Disponível em: http://comexstat.mdic.gov.br/pt/home, Acesso em 07 jul. 2021.

MERCOSUL, Mercado Comum do Sul, Países do Mercosul. Disponível em: https://www.mercosur.int/pt-br/quem-somos/paises-do-mercosul/. Acesso em 01 ago. 2021.

MINISTÉRIO DA ECONOMIA, Balança Comercial Consolidada e Séries Históricas. Disponível em: https://www.gov.br/produtividade-e-comercio-exterior/ptbr/assuntos/comercio-exterior/estatisticas/balanca-comercial-brasileira-acumulado-do-ano, Acesso em 03 ago. 2021.

MONASTERIO, L. M. Guia para Veblen: um estudo acerca da economia evolucionária. Pelotas: EDUFPEL, 1998.

NELSON, R. R. Recent evolutionary theorizing about economic change. Journal of economic literature, v. 33, n. 1, p. 48-90, 1995.

NORTH, D. C. Institutions, institutional change and economic performance. New York: Cambridge University Press, 1990.

Understanding the process of economic change. Princeton and Oxford: Princeton University Press, 2005.

PESSALI, H. F.; DALTO, F. A Mesoeconomia do desenvolvimento econômico: o papel das instituições. Nova Economia. v.20, n 1, p. 11-37, 2010.

RODRIGUES, B. A Geoeconomia híbrida da China na América do Sul: o uso de instrumentos econômicos duais para fins geopolíticos. Carta Internacional, v. 16, n. 1, p. e1085-e1085, 2021.

SDE-SC. Secretaria do Estado de Desenvolvimento Econômico. Indicadores Fiscais. PINTO, Kleber Carlos Ribeiro et al. Contribuição à análise de decisão sobre os sistemas de distribuição física do suco de laranja brasileiro de exportação. 2018.

SEF-SC. Secretaria do Estado da Fazenda do Estado de Santa Catarina. Valor adicionado por município e atividade. Disponível em: http://www.sef.sc.gov.br/servicos/servico/92/Valor_adicionado_por_munic\%C3\%ADpio_e_a tividade, Acesso em 07 jul. 2021. 
VEBLEN, T. B. A. A teoria da classe ociosa: um estudo econômico das instituições. São Paulo: Pioneira, 1965. (1a. ed. 1899).

Essays, reviews and reports: previously uncollected writings. DORFMAN, J (ed.). Inclui a introdução New Light on Veblen de Joseph Dorfman. Clifton, NJ: Augustus M. Kelley, 1973. 